\title{
Innovations for Declining Product to Extend Product Life Cycle (Case of TelX International Call Service Vinci)
}

\author{
Mahadi, Ardianto and Dhewanto, Wawan
}

\begin{abstract}
Change is rapid and unpredictable today. There are many emerging innovation that is used in society. There are many old and quite large today find themselves in business activities that have little promise for future growth and profit. Every firm need to manage their technologies and products, because the world is changing and new techologies emerge and the trade is shifting dynamically. Firms need to adapt, particularly in digital and telecommunication industries. Technology of internet changes the way of competition and value-creating model.

TelX International Call Service Vinci is one of PT TelX product to make an international call directly. This product is facing its decline phase according to product life cycle process. People start to leave TelX International Call Service Vinci and even do not know this product. However, this product can still give revenue for PT TelX. But, that revenue shows declining trend from over previous years. Innovation is needed to create more value for TelX International Call Service Vinci and extend the life of this product.
\end{abstract}

This research aim is to identify the factors that can influence the decline of TelX International Call Service Vinci and determine the innovations that are suitable and can be done for this product. This research uses qualitative and quantitative method. Qualitative data is collected from interview with Manager Regional Wholesale Service Telecommunication and observation in PT TelX. Quantitative data is collected through questionnaire from 70 respondents. Secondary data is collected from annual reports, journals, and books that support the research. Frameworks that used in this research are product life cycle framework and synergic innovation management model.

Decline of TelX International Call Service Vinci is caused by several factors. First is because the product has entered its mature stage. Second cause is less intensive marketing process from PT TelX for this product. Third is caused by the characteristic of customers. Low switching cost and niche market makes this product has little sales. Last factor is caused by other products that use newer technology for their products, for example the usage of internet. Innovations that are proposed for TelX International Call Service Vinci are change the packaging of TelX International Call Service Vinci and create attractive user interface for this product, partnering with VoIP (Voice ove Internet Protocol) provider to create better service, and sell TelX International Call Service Vinci in bundle with other Telecommunication services.

Index Terms-Declining Product, Innovation, Product Life Cycle, Product Life Extension

\section{INTRODUCTION}

People are now entering complex, emerging and unpredictable properties in business (Dodgson, Gann, \& Salter, 2008). Change is rapid and unpredictable. There are many emerging innovation that is used in society. There are many old and quite large today find themselves in business activities that have little promise for future growth and profit (Lamont, Hoffman, \& Forte, 1993). Companies and organization are struggling to create value and deliver it to consumers (Molina-Morales, Martinez-Chafer, \& ValienteBordanova, 2017). Every firm need to manage their technologies and products, because the world is changing and new techologies emerge and the trade is shifting dynamically (Khalil, 2000). Innovation and change are needed to gain and create competitive advantage today. Innovation becomes the driver for value creation and growth of any firm on the path to building a sustainable business or operation (Tchuta \& Fuji, 2017). Firms that are not doing any proper innovation, in a long run, will be wiped out by competitors that frequently introduce new business models, new products, and new processes that have superior added value to customers at lower costs (Tchuta \& Fuji, 2017). Firms need to adapt, particularly in digital and telecommunication industries. Technology of internet changes the way of competition and value-creating model. Internet creates disruption to many conventional technologies and let them to fall into declining phase in product lifecycle. Technologies such as fixed line telecommunication are entering the mature and decline phase because of the emerging technology of internets. These mature and decline phase must be managed well to avoid loss of profits and bad relationship with customers (Usanmaz, 2000).

PT TelX is large telecommunication company in Indonesia. This company has many products that are based on wireless telecommunication and fixed line telecommunication. In recent decades, there are many dramatic changes in mobile telecommunication technologies and services (Gao \& Damsgaard, 2007). Example for this condition is the changes from second generation telecommunication $(2 \mathrm{G})$ through the 2.5 generation $(2.5 \mathrm{G})$ to third generation (3G) (Gao \& Damsgaard, 2007), and today the technology is more advanced through fourth generation (4G) and massive internet technology diffusion. Many areas in PT TelX are disrupted by technology of internet, and one of them is international call services. This service is introduced in early 2000 and welcomed well by users. This service makes users can do international call to Telecommunication or other providers without any internet usage. This service needs innovation for gaining its competitiveness again today.

\section{METHODS}

\section{A. Conceptual Framework}

Framework in this research is concerned about managing product lifecycle and managing innovation to extend the product lifetime. Product lifecycle is used to determine the current condition of the product. Strategies may come from this framework. Conceptual framework for this research is shown in Figure 1. 


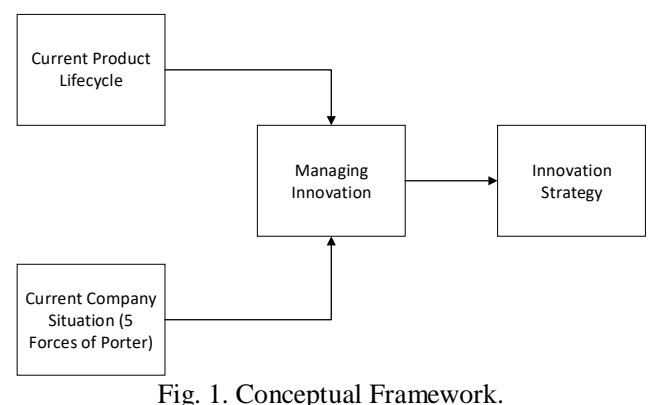

Framework starts from identifying product life cycle and examine product extension concept. Product life cycle is used to explain the current condition and position of product. Every position and phase in product life cycle has its own strategy and innovation concept. Current company situation is related with internal and external situation inside the company. Internal and external analysis is necessary to describe current situation. These findings are important to generate innovation and generate the strategy that is suitable with the company.

Managing innovation is about how the company's innovation meet the condition with need of current situation in the company. Managing innovation allows organization to respond external and internal condition, and use its creativity to make or create new ideas, processes or products. This kind of management is needed in terms to gain competitive advantage or power in wide areas of industry. Managing innovation is about how to create and adopt the innovation to users or customers. Innovation strategy is needed to create the strategy and action plan of TelX International Call Service Vinci product. Innovation strategy is filled with some plans of innovating current product in the market. The strategy can encourage advancement in technology or services. All of these strategies are used to gain competitive advantage. There are several strategies for innovation, from incremental innovation until radical innovation. Business process is related with linked tasks to find the end in delivery of service or product to customers. This activity can accomplish a specific organizational goal. This is the goal of management and goal of the innovation process in the company or organization. Managerial in Regional TelX Service should create the strategy and cascade it with the business process itself.

\section{A. 1. Product Life Cycle}

Product life cycle is a concept of a product phases, starts from introduction of a new product to its declining and disposal phase (Usanmaz, 2000). This concept is formalized by Theodore Levitt (1965), and stated the phases of the product life is from introductory, growth, maturity, decline and termination stage (Picard \& Hollander, 2017). This life cycle is following a pattern that is shown in Figure 2. According to the Usanmaz, most of products follow this product life cycle phases. The sales will grow from the start of introduction, until it reaches the maturity. After its maturity, the sales starts to decline and enters the termination phase. During the introduction until growth, the sales volume is low and the cost of production is high. In introduction phase, net profit of the firms is still low. The product's profit will reach its highest level between growth and maturity phase. This impact is depending on many factors (Usanmaz, 2000), for example as competitors' action, internal process characteristics, quality process and improvements and customer preferences. In maturity stage, marketing and production costs may increase, because of maintaining and penetrating the market share (Usanmaz, 2000).

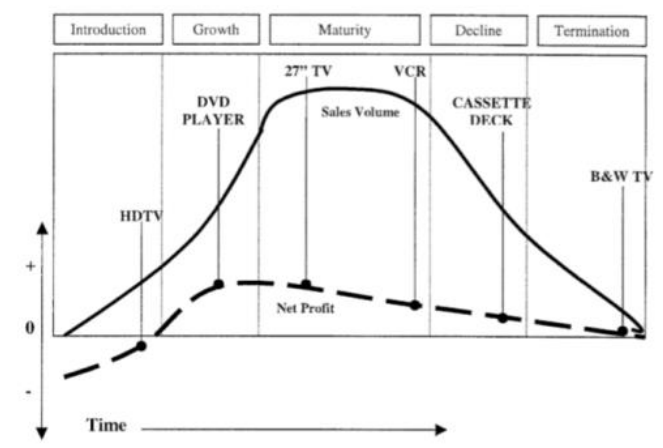

Fig. 2. Product Life Cycle Stages.

There are some critiques of the product life cycle concept (Usanmaz, 2000). Dhalla and Yuspeh (1976) said the product life cycle concept was too simplistic on each stage. This concept is not so valid in many areas (Dhalla \& Yuspeh, 1976). The conditions of product life cycle are not always followed the pattern directly from introduction to maturity, pass through the growth stage while others surged to quick peaks followed by a quick disappearance from marketplace. It is recommended to use marketing-communications model to measure the influence of different element on sales (Dhalla $\&$ Yuspeh, 1976). This will not be misled by minor sales into believing that a product or brand has entered declining stage.

This research is focused on declining phase of product life cycle. The decline may be fast or slow according to the situation (Picard \& Hollander, 2017). For example, VHS tapes was declined fast, while oatmeal cereals has slow decline. There are several factors and reasons why a product reaches the decline phase, one of them is because technological change. The emergence of a new product with new technology may bring additional benefits to customers (Picard \& Hollander, 2017). Demand is shifting because of the changes in technology, market tastes, regulations or other factors that create mature and declining phase (Anand, 2015). However, this decline phase still could be profitable. There are four situations when this condition occurs.

1. The product is still produced to fulfil the need of market whom cannot use new technology or the new products. Example of this condition is typewriters for those prison inmates who are not allowed to use computer.

2. There are a smaller market that prefers the older product. For example the market that are still using vinyl record to listen to the music.

3. Third condition in which a product in decline could be profitable is when it becomes a specialty product. For example a product or service with unique characteristic for which significant group of buyers is willing to make a special purchase effort. The product will transform into a luxury or exclusive goods in this condition.

4. Fourth condition is reincarnation or revival situation. This situation where the sales of the product that has entered the decline phase are gaining new vitality and often surpass its previous highest position (Picard \& Hollander, 2017). One possibility to gain this condition is the development of a new technology that is connected to the product itself. 


\section{A. 2. Current Company Situation}

Internal analysis in this research is based on resource analysis. There are two types of resources, which are tangible resources and intangible resources (Hitt, Ireland, \& Hoskisson, 2009). Tangible resources are assets which can be seen and quantified, such as equipment, facilities, buildings, etc. The value of tangible resources can be established through financial statements, but do not account for the value of the firm's assets. Intangible resources are assets which are relatively difficult to be seen, analysed and imitated. These resources are rooted deeply in the firm, for example knowledge, trust, capabilities, organizational routines, capabilities for innovation, brand and reputation. There are four types of tangible resources (Hitt, Ireland, \& Hoskisson, 2009), which are financial resources, organizational resources, physical resources, and technological resources. There are three types of intangible resources (Hitt, Ireland, \& Hoskisson, 2009), which are human resources, innovation, and reputational.

External analysis in this research is based on Porter's Five Force Model. Porter's five forces model determine the intensity of the industry competition and profitability (Arons $\&$ Waalewijn, 1999). These forces are analyzed and the strongest forces become crucial from the point of view of strategy formulation. Five Forces of Porter are barrier to entry, rivalry among existing competitors, subtitutes product, power of buyer and power of suppliers. Porter's Five Force Model is shown in Figure 3.

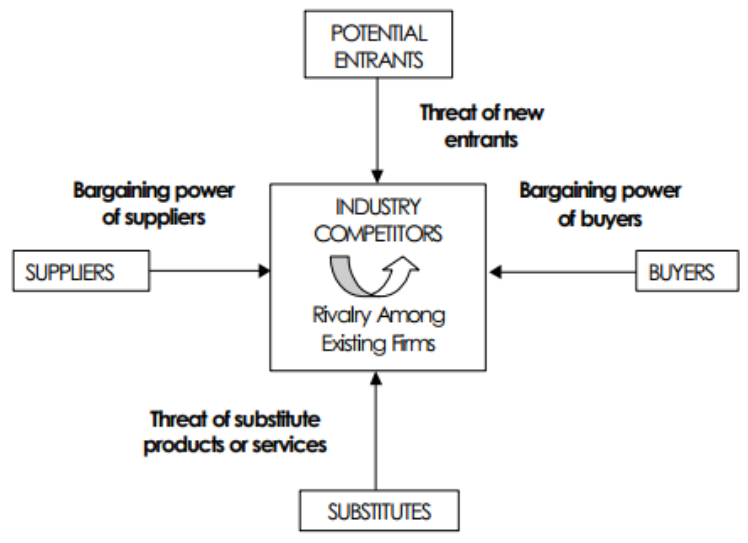

Fig. 3. Porter's Five Forces Model

\section{A. 3. Managing Innovation and Innovation Strategy}

Managing the innovation and technology are important today, because the change is happening very fast. Today, the approach must be very different and much more comprehensive (Khalil, 2000). Khalil stated that the management must deal with both stability and change. Management no longer manages in a static or stable technological environment. Management should manage in a highly dynamic and frequently turbulent environment (Khalil, 2000). Generating new ideas, creating new products, controlling production, innovate frequently are some challenges that are faced by today's managers. Management should utilize the existing capabilities of the organization to take the competitive advantage. Managers of technology must be able to react the external change or situation. When that technology reaches a stages of maturity and decline stage, that technology become commodity and available to all competitors (Khalil, 2000).
Innovations are important thing of expanding and developing new markets, as well as providing new function of the product (Molina-Morales, Martinez-Chafer, \& Valiente-Bordanova, 2017).

One model that can be used for managing the innovation is the synergic innovation management model (Tchuta \& Fuji, 2017). This model integrates the firm market, technology, and management innovations activities in way that enhances customer and business sustainability. This model transforms an idea or business opportunity into a sustainable business. Key activities in this model are strategy and financing, market development, technology development, and management development (Tchuta \& Fuji, 2017). Framework of this model is shown in Figure 4.

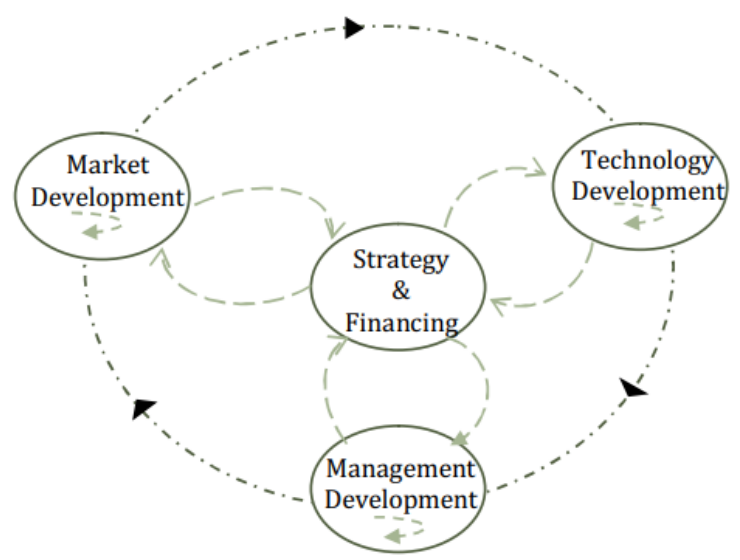

Fig. 4. Synergic Innovation Model

This model focus on other aspects beside technology development and product development, such as continuous and incremental development to provide value to the customer in efficient way. This model has two types of formal learning feedback loops and one formal iterating loop. First feedback loops connect market, technology, and management activity with the strategy and financing activity. Second feedback loops enable these activities to connect with multiple alternatives before feeding back the findings to the strategy and financing activity set. These feedback loops follow the plan, do, check, and act (PDCA) methodology (Deming, 1986).

Strategy and financing activities helps company to focus innovation process towards its grand vision. This is because a business or innovation initiative starts with an idea. Strategy and financing activities will help company to ensure the market position of the company is aligned with its core competence or by shifting its core competencies and align with better market position and capture more value and better opportunities in new market position. Activities of strategy and financing include developing a baseline business plan using business model canvas (Osterwalder \& Pigneur, 2010). This business model canvas constructs a business model of the business initiative, identify assumptions in the business model, make metrics to track progress of innovation with the business vision and re-evaluate the initiatives of business model.

Market development is needed to discover the customers and their needs. This activity helps the company identifies the real business opportunities for its vision. This activity have to be driven by innovation tracking metrics that is defined by the strategy and financing activities. This market development activity will go through series of experiments, then generate 
market innovation to compliment the technology, and management innovations.

Technology development activities focused on building the product or service for the business initiative. The technology development activities should be driven by the technology development metrics that are defined in the strategy and financing activities.

Management development activities is needed to ensure the minimum processes and resources required to deliver the value and outcome of technology development activities (product) to the outcome of the market development activities (customer) are available when needed. This minimum viable processes also helps company to validate the cost related hypothesis in its business model.

These activities are intended to three main objectives, which are:

1. Validate assumptions in the firm's business model

2. Align the firm's customers, products, and processes

3. Generate capabilities and core competencies that will drive further innovations and firm's positioning in a long term

\section{B. Data Collection}

Data collection in this research is done by qualitatively and quantitatively. Qualitative data is collected by interviewing the Manager of Regional Wholesale Service Telecommunication. Result of this interview is the issue that is faced by TelX International Call Service Vinci. The issue is about the product and its selling, mainly in these years. TelX International Call Service Vinci connects people to have an international peer-to-peer call easily, by using Telecommunication communication network. TelX International Call Service Vinci uses clear channel technology, so the digital information will be transmitted through circuit-switched network. This circuit-switched network has dedicated (non-sharing) characteristic, so one voice channel can only be used by one user. This characteristic gives clarity to the voice when doing an international call.

Quantitative data is collected through questionnaire from 70 respondents. The questions for the questionnaire is using framework from product life cycle, innovation process, and innovation strategy. The result of questionnaire is gathered by online method. The questions is divided into several parts, which are customer profile, international call service profile, innovation and product development profile. The question of this questionnaire is using 4-scale of likert scale. 4-scale is used to force the measure where no indifferent option available (ipsative) (Bertram, 2016). 4-scale of likert is also chosen because it is simple to generate and lower ambiguity in choosing the answer. There is no significant differences between 4-scale, 5-scale and 6-scale of likert (Leung, 2011). The finding is about the innovation profile and strategies that might be applicable for the solution. Respondent profile in this research is majority from student and employee in Bandung and Jakarta, which is around 17-25 years old. For in-depth question about international call with TelX International Call Service Vinci, the profile of respondent is a person who uses Telecommunication has made international call with TelX International Call Service Vinci before. Profile of respondent is shown in Table 1.
TABLE 1: Respondent's Profile

\begin{tabular}{|c|c|c|c|c|c|c|c|}
\hline \multicolumn{2}{|c|}{ Age } & \multicolumn{2}{|c|}{ Occupation } & \multicolumn{2}{|c|}{ TelX User } & \multicolumn{2}{|c|}{$\begin{array}{c}\text { TelX International Call Vinci } \\
\text { User }\end{array}$} \\
\hline $\begin{array}{c}\text { Des } \\
\text { c }\end{array}$ & $\begin{array}{l}\mathrm{Qt} \\
\mathrm{y}\end{array}$ & Desc & $\begin{array}{l}\mathrm{Qt} \\
\mathrm{y}\end{array}$ & $\begin{array}{c}\text { Des } \\
\text { c }\end{array}$ & $\begin{array}{l}\text { Qt } \\
\mathrm{y}\end{array}$ & Desc & Qty \\
\hline $\begin{array}{l}<17 \\
17-\end{array}$ & 0 & Employee & 28 & Yes & 40 & Yes & 8 \\
\hline $\begin{array}{l}25 \\
26-\end{array}$ & 45 & $\begin{array}{l}\text { Student } \\
\text { Entreprene }\end{array}$ & 26 & No & 30 & No & 32 \\
\hline $\begin{array}{l}35 \\
36-\end{array}$ & 13 & ur & 8 & & & & \\
\hline 45 & 3 & Teacher & 4 & & & & \\
\hline$>45$ & 9 & & & & & & \\
\hline
\end{tabular}

\section{RESULT AND DISCUSSION}

\section{A. Product Life Cycle}

TelX International Call Service Vinci is firstly launched in 2004, and it has been 15 years that the service is working. According to the product life cycle phase, this product is currently entering declining into termination phase. There are several evidence for that statement, for example:

1. Market aspects

a. The customer of this product is niche or special. According to the interview with head of Regional TelX Service, this product is mainly focused for a families who have their relatives or another family members whom stayed in other country (ex: immigrant worker, etc).

b. New generation customers (millennials) do not know about TelX International Call Service Vinci. It is based on the surveys that were conducted.

2. Product

The quality of this product is still good, but the problem is about the emerging technology that is coming in this era. Technology of internet changes the model for customer to make an international call. New generation would like to use internet based call instead of TelX International Call Service Vinci.

Although it is declining, TelX International Call Service Vinci service has not terminated yet by PT TelX. It is because TelX International Call Service Vinci still captures about 5\% of overall Telecommunication revenue per year. However, TelX International Call Service Vinci is facing challenge about the future. According to data, TelX International Call Service Vinci revenue trend is declining through the past periods.

\section{B. Current Company Situation}

PT TelX and Regional TelX Service have decent resources now. Resources are divided into tangible resources and intangible resources, and explained below:

1. Tangible Resources

a. Financial Resource: PT TelX has healthy financial status. From annual report, PT TelX's annual income is growing by $10 \%$.

b. Organizational Resources: PT TelX has good reputation and culture in organizational resources. PT TelX has good and competent teams to achieve the organization goals.

c. Physical Resources: PT TelX has many infrastructures and buildings assets to provide the best service to customers

d. Technological Resources: PT TelX has many technological resources and technological 
development program, such as Amoeba, internet broadband, network database

2. Intangible Resources

PT TelX has some valuable intangible resources. For example, PT TelX has a good managerial and organizational capabilities, has good capacity to innovate, has good reputation with customers and big brand name in Indonesia, and has good perception of product quality and reliability.

External factors of TelX International Call Service Vinci is described by Five Forces of Porter. Explaination for each force in TelX International Call Service Vinci product is shown in Table 2.

TABLE 2: Five Forces of Porter of TelX International Call Service Vinci

\begin{tabular}{ll}
\hline \hline Force & Description \\
\hline Barriers to Entry & Low \\
Rivalry Among Competitors & Low \\
Subtitutes Product & High \\
Power of Buyers & High \\
Power of Suppliers & Low \\
\hline \hline
\end{tabular}

Other company or new company is relative hard to enter this industry. For making an international call service, a firm need to build core infrastructure and regulations. New competitor needs to have adequate capital requirement and follow several government policies. According to this condition, threat from barriers to entry is relatively low. Number of competitors in this sector are low, for example Alpha International Calls Service and Beta International Call Service. The diversity among these competitors is not so much, and the quality difference among these services is low. The growth in this industry is relative low and the barriers to exits from this sector of industry is relative high due to the high investment of international call infrastructures. According to these findings, the rivalry among existing competitors is medium. There are several subtitute products of international call service. Number of subtitute products available are many, for example voice chat through internet service and video call through internet service. These services are provided by for example WhatsApp Call Application, Line Call Application, Skype Application Service, etc. The power of internet changes the core model of international call service model. Buyers also have good propensity and response to these subtitute products. Ease of access to internet will make buyer tend to use these subtitute products than Telecommunication's TelX International Call Service Vinci. The price to performance ratio of these subtitute products are relative low than TelX International Call Service Vinci service. The switching costs to subtitute products are low. According to those finding, the threat of subtitute products are high. Buyers have a strong power to determine the service that they want to choose. Buyers are very sensitive to the price of the core service and the subtitute products. They have ability to choose subtitute products of TelX International Call Service Vinci service. The ease of information availability and low switching costs to other products. According to these findings, the bargaining power of buyers are relatively high. Suppliers of PT TelX are technological companies that support the infrastructure of telecommunication service, for example PT Gamma (Indonesian Telecommunication Industry). This company is owned by government, and routinely provides the supply for PT TelX. According to these findings, the bargaining power of suppliers is relative low.

Based on findings, the problem or decline of TelX International Call Service Vinci is caused by four main cause, which are the product, marketing process, consumer, and external situation of the business. Product's cause has three sub-causes, which are still using old technology, lack of features, and lack of innovation. This innovation problem is caused by two sub-causes, which are not concern in innovation and lack of innovative environment or culture. Second main cause is from marketing process. This cause is concerned about the selling process and capturing more sales in the market. The marketing cause has two sub-causes, which are marketing is not intensive and not targeting young consumer. Marketing process is not intensive is caused by low marketing budget for this product. Third main cause is consumer. This main cause is about the preferences of consumers about the product or services that is offered in the market. This consumer cause is caused by two sub-causes, which are power of buyer is high and niche consumer. High power of buyer is caused by low swithcing cost. Last main cause is external situation. This cause is mainly concerned about the external factor and situation that affected the internal business and situation of the business. This cause has two sub-causes, which are internet technology disruption and many new competitors in telecommunication service, which are using new technology and more innovative.

There are also several findings from questionnaire. First finding is about the product innovation and development for the mature and declining products, regarding of product life cycle framework. This question is asked to get the insight about importance of product revival or extension after its maturity or declining. According to the result, majority of respondents agree with the importance of product extension after its maturity, with average score is 3,20 (out of 4,00). Continuous development is needed to make sure the product still remains in the market. Majority of respondent also think the development of products or services is important.

Next finding is the insight about combining old product with newer product or features. This concept is come from the framework of product renewal and innovation strategy. Most of respondents are agree with the combination of old product with newer innovation of product or services, with average score is 3,42 . It means, the old product can innovate through the combination of latest innovation or novel innovation of the product.

Next finding is about the quality of current call service with internet based technology, for example Whatsapp, Skype, Line Call, etc. This question is asked to get the insight about current quality of another competitor products and become the opportunity to compete with them. Based on the result, majority of respondents answered that the quality of internet based call (VoIP) is not good or on average, with the score of result is 2,59 .

Next finding is about the quality of current non-internet call service. This question is asked to get the insight about quality of current non-internet call service and become the strength to compete with other products. Based on the result, majority of the consumer feel that non-internet call service is 
good with the mean of result is 3,30.

Next finding is about the quality of current non-internet call service if compared with internet based call service. This question is asked to get the insight about quality of current non-internet call service compared with the internet call service. According to the result, non-internet call service is better than the internet call service, shown in the result with mean 3,55. Non-internet call service has better clarity in voice and there is no delay when doing a call.

Next finding is about the opinion if internet call service has the clarity of non-internet call service. This question is asked to get the insight about the innovation if internet call service has a technology like non-internet call service. Majority of respondents are strongly agree with this combination with the mean result is 3,86 , The internet call service should has a clarity and quality as like as non-internet call service.

Next finding is about the preference of respondents about the cost. This question is asked to get the insight about the willingness of customer to spend extra cost to get better quality for internet based call service. Majority of the respondents have willingness to spend extra cost to get better quality of internet call service.

Next finding is about the preference of respondents about the bundling of product. This question is asked to get the insight about the preferences of customer about the bundling features for current international call service/product. Majority of the respondents are agree if the package of international call service is bundled with other package, with the mean of result is 3,07 .

Last finding is about the spesification that is needed for international call service. This question is asked to get the insight about the customer preferences about the features that are needed for international call service. Respondents want the service has a clear sound as the main spesification of international call service. Respondent also want the package price as main spesification of international call service.

Next is the finding about TelX International Call Service Vinci product. There are several questions about TelX International Call Service Vinci to get the insight and opinion about quality of TelX International Call Service Vinci. From respondents who have ever done international call service, they were asked whether they have ever used TelX International Call Service Vinci or not. From all respondents who have ever had international call, there are only $29,6 \%$ who ever used TelX International Call Service Vinci product, and there are only $7,1 \%$ who are still using it today. Insight from this result is the user of TelX International Call Service Vinci product is not much compared with other services. Figure 5 shows that there are another services that respondents used for their international call service.

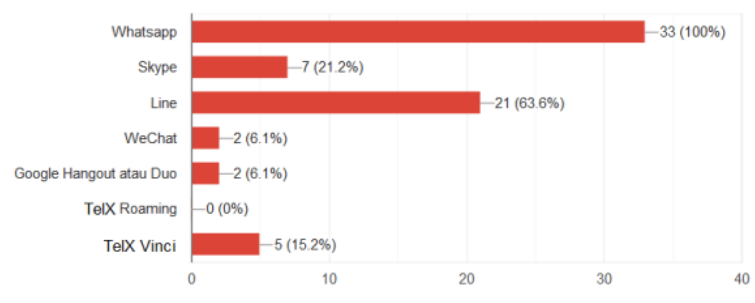

Fig. 5. Services That Used for International Call
From the result above, respondent majority used VoIP call service for their international call. Whatsapp is the most preferred product to make an international call. Line Call is the second and Skype is the third.

Next finding is about the quality of TelX International Call Service Vinci product. This result is shown in Figure 6. From the result, majority of TelX International Call Service Vinci users responded that the quality of TelX International Call Service Vinci is very good, with the mean of result is 3,71 .

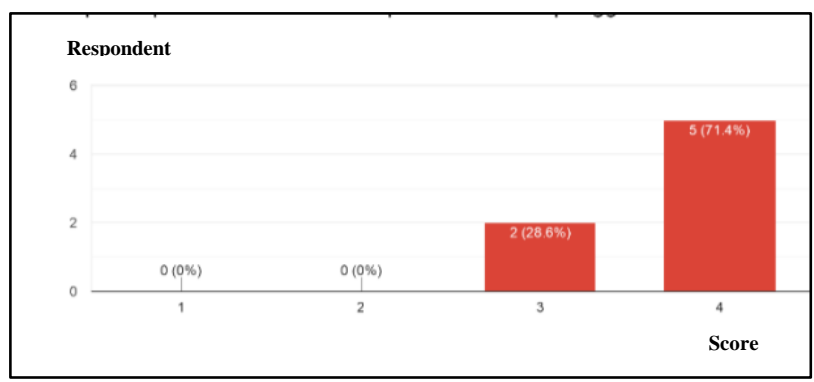

Fig. 6. Quality of TelX Interntional Call Service Vinci Product

\section{Innovation Strategy}

The proposed solution is based on the innovation process and strategy. Innovation is chosen because this product is needed to be extended or revived in product life-cycle framework. There are several innovation process or types, for example product innovation, process innovation and business model innovation. The strategy will implement strategy innovation and managing innovation process. The innovation strategy in this research focused on customer excitement, competitive leadership and portfolio enrichment (Bowonder, Anirudha, Kumar, \& Shirodkar, 2015). The innovation management in this research will use Synergic Innovation Management Model (Tchuta \& Fuji, 2017).

Customer excitement strategy is one of innovation strategy that will excite the customer through the product's distinct value proposition. The objectives of this strategy are to create more value of the product to the market, bring superior offering through the present offering, and deliver new customer experiences. Strategy that are used for customer excitement are platform offering and brand value enhancement. Platform offering will share a common technology and address related market segments. Brand value enhancement will enhance the value of the product through distinct product and services experiences. This strategy could be done by improve current TelX International Call Service Vinci product from its experience when using it. For example by increasing ease of use when activating the package. This experience could give more value and excitement to the customer, and TelX International Call Service Vinci product could attract more users.

Competitive Leadership Dimension is used to dominate competition by outwitting, outmaneuvering and outperforming through innovation. Strategy that is used in this dimension is partnering. Partnering helps the company or firm to synergize complementary capabilities besides sharing resources and risks. In this strategy, two firms collaborate each other to create more value and technology. Partnering strategy will reach more opportunities in the market and reach more customers. TelX International Call Service Vinci product is a good service for international call. Based on questionnaire, $71,4 \%$ that had used or still using TelX International Call Service Vinci product said that the service 
and quality is very good and $28,6 \%$ said that TelX International Call Service Vinci is good. This factor can be a strength for TelX International Call Service Vinci reach the market for international call service. Otherwise, TelX International Call Service Vinci is not known well and not used by majority of telecommunication users. Based on data, $84,8 \%$ of respondents do not use TelX International Call Service Vinci for their main international telecommunication service. They prefer to use VoIP (Voice over Internet Protocol) instead of non-internet service (TelX International Call Service Vinci or roaming service). On other hand, VoIP service does not have good quality or clarity in voice when calling. Based on quesionnaire, VoIP call service have a 2,59 score out of 4 , which means below of good criteria. The advantage of these VoIP providers is they are known well and has a large users, particularly in millenial age users (below 40 years old). Telecommunication could use this situation and opportunity to have a partnership with one of the VoIP provider company, for example WhatsApp, Line Call and Google Duo or Hangout. TelX International Call Service Vinci has better quality in voice because of its clear channel technology. This partnering strategy will give both parties possible advantages, as shown in Table 3.

TABLE 3: Partnering Advantage for Telecommunication and VoIP Providers

\begin{tabular}{|c|c|c|}
\hline & Telecommunication & VoIP Provider \\
\hline \multirow[t]{2}{*}{ Advantage } & $\begin{array}{lr}\text { Reach new } & \text { the } \\
\text { telecommunication } & \\
\text { service market, } & \text { particularly } \\
\text { international in } \\
\text { service }\end{array}$ & $\begin{array}{l}\text { Shared technology and } \\
\text { infrastructure from } \\
\text { Telecommunication will } \\
\text { gain the quality of calling } \\
\text { service and could gain } \\
\text { more users }\end{array}$ \\
\hline & $\begin{array}{l}\text { Gain more revenue from } \\
\text { reached customers that } \\
\text { are using this service }\end{array}$ & $\begin{array}{l}\text { Gives possibility for new } \\
\text { revenue stream through } \\
\text { premium international } \\
\text { call subscription }\end{array}$ \\
\hline
\end{tabular}

Portfolio Enrichment strategy will enrich the product portfolio by adding more innovative product offering and features. This strategy could create new market opportunities. This strategy will create more features into current product, either it is mature or growing. The strategy that is used in this dimension is create or reach new market segmentation by adding bundle to TelX International Call Service Vinci product. Bundling helps firm to create more attractive product and more valuable offering to the customers. Bundling allows the consumers to find one product that offers several solutions. This strategy can increase sales and profits on each individual product, especially for TelX International Call Service Vinci product. There are several products or features that are bundled in this strategy. The bundled products are internet package, free SMS and non-internet call features and entertainment features (video and music streaming). Internet package is chosen as one of the bundled product because internet package can attract more users from internet user segment. Free SMS and non-internet call service is chosen because it can attract more users from non-internet user segment. Entertainment features is chosen to attract more users from entertainment and streaming features. Entertainment product that can be bundled. In this situation, the proposed products to be bundled are international call service, Telecommunication SMS and Telecommunication phone call service, internet service, and entertainment service. Example of proposed bundling package is shown in Table 4.
TABLE 4: Proposed Bundling Package

\begin{tabular}{ll}
\hline \multicolumn{1}{c}{ Product } & \multicolumn{1}{c}{ Description } \\
\hline International Call (TelX & 300 minutes \\
International Call Service & \\
Vinci) & \\
SMS & $100 \mathrm{SMS}$ \\
Phone Call & 50 minutes \\
Internet & $6 \mathrm{~GB}$ \\
Entertainment & $8 \mathrm{~GB}$ \\
Period & $1 \mathrm{Month}$ \\
Proposed Price & $\mathrm{Rp} 100.000,--$ \\
\hline \hline
\end{tabular}

\section{Managing Innovation}

Managing innovation is needed when implementing the innovation in a firm. Management should manage the ideas, new products, controlling the production and think about next innovation that should be done. Managing innovation for this case is using synergic innovation management model by Tchuta and Fuji (2017). There are four key activities that is done in this model, which strategy and financing, market development, technology development, and management development. This model will focus on many aspects besides product and technology development. This will allow continuous and incremental development to provide value to customer in efficient way. This model has two main loops, which are feedback loops between strategy and financing with three main activities set and one iterating loop between market development, technology development, and management development. Feedback loops is used to integrate main activities with firm's strategy and align them. Iterating loop is a way to find the innovation and development from technology development to management development and finally to market development. Start point of this iteration depends on the situation of the firm. For example, startup company is suitable to find its market and then develop the technology first, then develop its management.

Each process or activity has implication and feedback into main strategy of the firm. According to previous section, Telecommunication strategy are to deliver more value to customer through product innovation and services, gain more synergies and build better digital ecosystem to domestic market and international market, enrich portfolio with TIMES (Telecommunication, Information, Media, Edutainment, and Services), and gain support using strategic control to align business units, functional units, and subsidiaries. Explaination for this is shown below:

a) Key Activities: Market Development

- Process or Activities: Find and discover customer needs, features and opportunity from customer. Telecommunication should find another market based on the strategy. TelX International Call Service Vinci product will reach more millennial users with its package, interfaces and its features. Partnering with VoIP providers can increase attention from these users. Bundling strategy also could reach another market. Telecommunication could find new market that needs several products or solution in one package.

- Feedback with Firm's Strategy: This activity is aligned with gain more synergies and build better digital ecosystem to domestic market and international market strategy and deliver more value to customer through product innovation and services.

b) Key Activities: Technology Development 
- $\quad$ Process or Activities: Telecommunication can start to create its minimum viable product (MVP) from its strategy. There are three main technological or product development in this phase:

1. Telecommunication starts to create more intuitive and attractive interfaces to activate the TelX International Call Service Vinci package.

2. Creates partnertship and technological development together with another party to make international call service more robust. These parties could share current technology and develop new technology to create better quality in call services. For example, Telecommunication and VoIP provider create a product for international call in VoIP application base but with the clear channel technology.

3. Starts to make bundling package with another Telecommunication product. This will help increasing TelX International Call Service Vinci and another bundled products sales.

- Feedback with Firm's Strategy: This activity is aligned with the deliver more value to customer through product innovation and services strategy and enrich portfolio with TIMES (Telecommunication, Information, Media, Edutainment, and Services). This activity also allows parent company to align and gain support for its subsidiaries and another business units through bundling program, for example international and wholesale business units with consumer business units (Telecommunication).

c) Key Activities: Management Development

- Process or Activities: Management should support the innovation process that is proposed. Management should initiate the team and budget to handle this innovation process, from developing the market until the product and technology development process.

- Feedback with Firm's Strategy: This activity gain support for another units using strategic control to align business units, functional units, and subsidiaries.

There are some resources needed for the implementation. The resources for doing the activities are human resources, technology resources, and monetary resources. Explanation of each resources is shown below:

1. Human Resources - innovation in a firm needs a team. This HR is needed to implement the new ideas, methods and technologies that is proposed and planned. Telecommunication could make an ad hoc team for the innovation program and Telecommunication should provide the mentor to monitor the progress of the activities. This small team have the authority to build up the program, but still monitored by the management. There are some characteristic of the team for succeeding the innovation process. One of them is the entrepreneurial characteristic of each team member. This characteristic is needed to provide the innovation and change easily, because the spirit of entrepreneurial in the company encourages the members to make the change, especially in established company.

2. Technology Resources - Telecommunication should provide the technology that they have for those activities. For example, Telecommunication should provide the clear voice technology for partnering activity, and another example is Telecommunication should provide the technology for creating more attractive interface and bundling program. In bundling program, Telecommunication should provide the products or services from another business units, for example consumer segments (SMS and internet package) to be bundled with TelX International Call Service Vinci package.

3. Monetary Resources - Telecommunication should prepare and have budget for the innovation process. Telecommunication could allocate their $1 \%$ until $5 \%$ of the revenue for research and innovation budget.

\section{CONCLUSION}

TelX International Call Service Vinci is one of mature product that facing its decline phase in product life cycle. Many newer product and service that provides the same or even better than TelX International Call Service Vinci product. TelX International Call Service Vinci still remains because it is still capturing decent revenue, even though this product is entering its declining phase. There are some evidence that makes TelX International Call Service Vinci entering mature and declining phase, such as only used by small and special market or users, little awareness by newer generation, and many new technological that using internet distrupt TelX International Call Service Vinci. Innovation in this product is needed if TelX still wants to retain TelX International Call Service Vinci.

There are several innovation that can be applied to TelX International Call Service Vinci. First one is to excite the customer through new experience when using the product. The product could deliver more value from the product when using the package. Creates interfaces and gives the ease of use when using this product could increase the excitement of customers. Second is to gain competitive leadership from the competitor. Strategy that is used by partnering with other party that is using VoIP call service. The purpose of this strategy is to reach new market and gain more awareness from new generation customers that is more likely to use interned based call service. Third is to enrich the portfolio of the product. Strategy for this innovation is to bundle the product with other services. Bundling helps firm to create more attractive product and more valuable offering to the customers and also allows the consumers to find one product that offers several solutions. Bundling for this strategy is with internet package, free SMS and non-internet call features and entertainment features (video and music streaming).

\section{REFERENCES}

[1] Anand, J., "M\&A Strategies in Mature and Declining Industries: Theoretical Perspective and Implications," Advanced in Mergers and Acquisitions, pp. 163-179, 2015.

[2] Arons, H. d., \& Waalewijn, P., "A Knowledge Base Representing Porter's Five Forces Model," Rotterdam: Erasmus University Rotterdam, 1999.

[3] Bertram, D., Likert Scale, 2016.

[4] Bowonder, B., Anirudha, D., Kumar, S., \& Shirodkar, A., "Innovation Strategies for Creating Competitive Advantage," Research-Technology Management, pp. 19-32, 2015.

[5] Deming, W. E., Out of the Crisis. Cambridge: Cambridge, Mass. : Massachusetts Institute of Technology, 1986.

[6] Dhalla, N. K., \& Yuspeh, S., "Forget the Product Life Cycle Concept!" Harvard Business Review, 102, 1976. 
[7] Dodgson, M., Gann, D., \& Salter, A., "The Management of Technological Innovation, New York: Oxford University, 2008.

[8] Gao, P., \& Damsgaard, J., "A Framework for Understanding Mobile Telecommunications Market Innovation: A Case of China," Journal of Electronic Commerce Research; Long Beach Vol. 8, Iss. 3, pp. 184-195, 2007.

[9] Hitt, M. A., Ireland, R. D., \& Hoskisson, R. E., Strategic Management Concept \& Cases 8th Ed. Mason, OH: South-Western Cengage Learning, 2009.

[10] Khalil, T., Management of Technology The Key to Competitiveness and Wealth Creation. Singapore: McGraw-Hill Book, 2000.

[11] Lamont, B. T., Hoffman, J. J., \& Forte, M., "Competitive Decision Making in Declining Industries," The International Journal of Organizational Analysis, pp. 203-215, 1993.

[12] Leung, S. O., "A Comparison of Psychometric Properties and Normality in 4-, 5-, 6-, and 11-Point Likert Scales," Journal of Social Service Science 37:4, pp. 412-421, 2011.

[13] Molina-Morales, F. X., Martinez-Chafer, L., \& Valiente-Bordanova, D., "Disruptive Technological Innovations aNew Opportunities for Mature Industrial Clusters. The Case of Digital Printing Innovation in the Spanish Ceramic Tile Cluster," Investigaciones Regionales Journal of Regional Research, pp. 39-57, 2017.

[14] Osterwalder, A., \& Pigneur, Y., Business Model Generation: A Handbook for Visionaries, Game Changers, and Challengers. New Jersey: John Wiley \& Sons, Inc, 2010.

[15] Picard, J., \& Hollander, A., "Does the Decline Phase of the Product Life Cycle Ends Up in Death?" Proceedings of the 11th Asia-Pacific Conference on Global Business, Economics, Finance and Business Management, 2017.

[16] Tchuta, L., \& Fuji, X., "Towards a synergic innovation management model: the interplay of market, technology, and management innovations," International Journal of Business and Economic Development Vol. 5 Number 1, pp. 60-70, 2017.

[17] Usanmaz, G., End-of-Life Cycle Product Management, 2017.

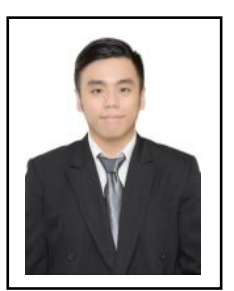

Mahadi, Ardianto born in Jakarta, on $2^{\text {nd }}$ September of 1995. Educational background is Bachelor of Industrial Engineering (2017) at Parahyangan Catholic University, Bandung, Indonesia and Master Degree of Business and Administration at Institut Teknologi Bandung, Bandung Indonesia (2019).

He worked at PT Eksonindo Multi Product Industry in 2016 as Operation Staff to measure standard operating time and balance production lines and worked at PT TelX Tbk in 2019 as Wholesale and Marketing Analyst to analyze and improve the sales and marketing programs of TelX. 